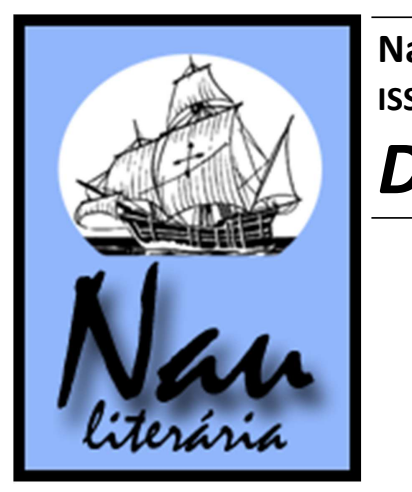

Nau Literária: crítica e teoria de literaturas • seer.ufrgs.br/NauLiteraria

ISSN 1981-4526 • PPG-LET-UFRGS • Porto Alegre • Vol. 07 N. $01 \bullet$ jan/jun 2011

Dossiê: literaturas africanas de LP

\title{
A presença da voz em Niketche, de Paulina Chiziane
}

\section{Cristina Mielczarski dos Santos}

\begin{abstract}
Resumo: Niketche, palavra que dá nome ao livro, é uma dança tradicional do norte de Moçambique. Essa informação cultural e muitas outras são abordadas por meio da narrativa de Paulina Chiziane. A escritora é a primeira a publicar um romance no país, cuja atividade literária é totalmente liderada por homens. O tema que permeia o romance é a poligamia, e, nesse contexto, evidencia-se a cultura local por intermédio das lendas e dos rituais de iniciação que fazem parte da tradição oral. Também os provérbios marcam essa presença na linguagem do texto.
\end{abstract}

Palavras-chave: Literatura Africana; Oralidade; Keywords: African literature; Orality; Proverbs.

\begin{abstract}
Niketche, the word which names the book, is a traditional dance of Northern Mozambique. This cultural information, as well as many others of the kind, are addressed by Paulina Chiziane's narrative. The writer is the first one to publish a novel in a country where the literary activity is fully led by men. Polygamy is the theme that permeates the novel, and, on this context, it highlights the local culture through the use of the legends and rituals of initiation that are part of the oral tradition. Proverbs also mark this presence in the language of the text.
\end{abstract}

Provérbios.
Poligamia é uma rede de pesca lançada ao mar. Para pescar mulheres de todos os tipos. Já fui pescada. As minhas rivais, minhas irmãs, todas, já fomos pescadas. Afiar os dentes, roer a rede e fugir, ou retirar a rede e pescar o pescador? Qual a melhor solução?

Paulina Chiziane

O termo "oral" vem do latim "os, oris" (BUSARELLO, 2004, p.190), e significa boca, linguagem, enunciado pela voz, que se transmite de indivíduo a indivíduo pela palavra falada, verbal, vocal. Daí o termo oralidade, qualidade do que é oral ${ }^{1}$, cuja expressão, segundo o antropólogo Eric Havelock (1995, p.17), caracteriza as sociedades que "têm se valido da comunicação oral, dispensando o uso da escrita". O autor também afirma que a oralidade é "usada para identificar um certo tipo de consciência, que se supõe ser criada pela oralidade ou que pode se expressar por meio dela" (HAVELOCK, 1995, p.17). Então, de acordo com tais considerações, é interessante observar como se processa esse "tipo de consciência" através da oralidade na Literatura Africana de Língua Portuguesa.

\footnotetext{
* Mestranda em Letras pela Universidade Federal do Rio Grande do Sul (UFRGS), na área de Literaturas Portuguesa e Luso-Africana.

1 Larousse cultural - Dicionário da Língua Portuguesa. São Paulo: Editora Nova Cultural Ltda., 1992.
} 
Pode-se dizer que o termo "dispensar o uso da escrita", em se tratando precisamente de Moçambique ${ }^{2}$, não é o mais específico. Esse país, na atualidade, apresenta um percentual de $80 \%$ de sua população não-letrada e não é simplesmente por opção e, sim, por uma imposição político-social de um território devastado por duas guerras consecutivas: Guerra Anti-colonial (1965-1975) e Guerra Civil (1976-1992). Entretanto, nesse momento, a discussão em pauta não é sobre política. Tampouco envolve questões como oralidade em oposição à cultura escrita. $\mathrm{O}$ escopo é travar um movimento dialético entre a escrita e a oralidade. Para tanto, faz-se necessário elucubrar na obra da escritora moçambicana Paulina Chiziane elementos da oralidade como os provérbios, os ditos populares, as expressões cotidianas e máximas constantes no imaginário africano. Conforme esses aspectos, muitos dos provérbios também circulam na tradição oral brasileira.

\section{Origens}

A oralidade, nos anos 60 do século $\mathrm{XX}$, teve um número significativo de estudiosos que a colocaram em evidência: A galáxia de Gutenberg (The Gutenberg Galaxy), de Mchluhan (1962), O pensamento selvagem (La pensée sauvage), de Lévi-Strauss (1962), As consequências da cultura escrita (The consequence of Literacy) de Jack Goody e Ian Watt (1963) e também Prefácio para Platão (Preface to Plato) de Havelock (1963). Mesmo que tenha sido explorada essa temática em tal década, já em 1928, Milman Parry, com O epíteto tradicional em Homero (L'Epithète tradionelle dans Homère), tinha inaugurado esse gênero. Sendo assim, estudos e discussões sobre a Literatura oral não são recentes e permanecem até a contemporaneidade.

Em 1982, o padre jesuíta Walter Ong, em sua obra Oralidade e cultura escrita (Orality and Literacy), destaca o seguinte: denomina-se "culturas de oralidade primária as que se definem por desconhecerem a escrita ou impressão gráfica, e culturas de oralidade secundária aquelas em que a expressão e a criação dependem da escrita e da impressão" (ONG, 1998, p.41). O autor aborda também que a comunicação oral ampara-se na alta tecnologia - rádio, telefone, televisão. Nesse contexto, é mais relevante tratarmos do capítulo três, "Sobre a psicodinâmica da oralidade", no qual constam especificidades do pensamento estruturado em sociedades de cultura oral primária. Segundo Ong (1995, p.42), sem a escrita

\footnotetext{
${ }^{2}$ A taxa de alfabetização, de acordo com o Programa das Nações Unidas para o Desenvolvimento de 2007/2008. Resultado: posição 169 Moçambique 38,7. Disponível em: http://pt.wikipedia.org/wiki/Lista_de_países_por_Índice_de_analfabetismo. Acesso em 02 maio 2010. O índice de alfabetização em Moçambique é de menos de 50 por cento, com quatro dentre cinco mulheres e um de cada três homens incapazes de ler. Disponível em: http://news.adventist.org/pt/2008/10/mocambique-mais-equatrocetos-aultos-apreem-a-ler-e-escrever--.html. Acesso em 02 maio 2010.
} 
"as palavras em si não possuem uma presença visual, mesmo que os objetos que elas representam sejam visuais. Elas são sons." O teórico afirma ainda que os povos orais consideram as palavras dotadas de grande poder: "O som sempre exerce um poder" (ONG, 1998, p.41). Ele inclusive aponta inúmeras características do pensamento e da expressão fundados na oralidade. Dentro dessa perspectiva, será dada maior ênfase à estilização formular:

\begin{abstract}
Numa cultura oral primária, para resolver efetivamente o problema da retenção e da recuperação do pensamento cuidadosamente articulado, é preciso exercê-lo segundo padrões mnemônicos, moldados para uma pronta repetição oral. O pensamento deve surgir em padrões fortemente rítmicos equilibrados, em repetições ou antíteses, em aliterações e assonâncias, em expressões epitéticas ou outras expressões formulares, em conjuntos temáticos padronizados, em provérbios que são constantemente ouvidos por todos, de forma a vir prontamente ao espírito, e que são eles próprios modelados para a retenção e a rápida recordação - ou em outra forma mnemônica. (ONG, 1998, p.45)
\end{abstract}

O autor parte do princípio de que, nessas culturas, a palavra é um produto sonoro que determina "os modos de expressão e os processos mentais". O questionamento basilar se evidencia, assim, da seguinte maneira: como os autores empregam elementos característicos da oralidade na literatura escrita?

Sob o viés do antropólogo Amadou Hampaté Bâ, quando falamos de tradição africana, reportamo-nos para a tradição oral:

Nenhuma tentativa de penetrar a história e o espírito dos povos africanos terá validade a menos que se apóie nessa herança de conhecimentos de toda espécie, pacientemente transmitidos de boca a ouvido, de mestre a discípulo, ao longo dos séculos. (HAMPATÉ BÂ, 1980, p.181)

Um dos representantes da tradição oral transmitida de "boca a ouvido" é o provérbio que pertence ao "repertório artístico da textualidade oral" (MOREIRA, 2003, p.170) e que endossa a voz oracular assumindo no texto uma conotação poética.

\title{
2 A oralidade na obra de Paulina Chiziane
}

Paulina Chiziane nasceu em Monjacaze, província de Gaza, sul de Moçambique. Ela é considerada uma das primeiras mulheres a escrever um romance em seu país. No entanto, Chiziane afirma não escrever romances e, sim, estórias. Nas palavras da autora: "sou contadora de estórias e não romancista. Escrevo livros com muitas estórias, estórias grandes e pequenas. Inspiro-me nos contos à volta da fogueira, minha primeira escola de arte." (CHIZIANE, 2002, contracapa). Sua “contação" de histórias está no sangue, herança de sua avó, que pertencia ao grupo étnico macagandane. Atualmente, a escritora mora e trabalha na Zambézia, norte do país. 
A escritora escreveu A balada de amor ao vento (1990), Ventos do Apocalipse (1995) e $O$ sétimo juramento (1999), entre outros. No entanto, é analisado neste trabalho o romance Niketche: uma história de poligamia (2002), cujo nome deriva de uma dança sexual feminina, aprendida pelas meninas durante os rituais de iniciação, para que afirmem ao mundo que são mulheres. A dança macua é originária da Zambézia, região norte de Moçambique. Nessa perspectiva, a autora, no corpo da narrativa, explicita sobre esse ritual:

"Niketche. É a dança do sol e da lua, dança do vento e da chuva, dança da criação. Uma dança que mexe, que aquece. Que imobiliza o corpo e faz a alma voar. [...] Movem o corpo com arte saudando o despertar de todas as primaveras. Ao toque do tambor, cada um sorri, celebrando o mistério da vida ao sabor do niketche." (CHIZIANE, 2004, p.160).

Nesse livro, a autora conta a história do comandante António Tomás, o Tony, e da sua mulher Ana Maria, a Rami. A ficção ocorre no presente, sendo narrada em primeira pessoa por ela, a narradora-protagonista. É por intermédio de sua voz que ouvimos a história dela e também das amantes de seu marido e de tantas outras mulheres que contam suas trajetórias de vida. Seus percalços enquanto indivíduos do sexo feminino ocorrem frente a uma sociedade dividida deste modo: Feminino/Masculino, Matriarcal/Patriarcal, Monogamia/Poligamia, Tradição/Contemporaneidade, Norte/Sul.

O romance é permeado pela cultura africana, com suas lendas, mitos e riquezas da tradição oral. Ao longo da leitura surge um mosaico de culturas: maconde, macua, ronga, tsonga, machangana. O legado dessas culturas é apresentado por intermédio de Rami (etnia ronga), e pelas outras mulheres de Tony: Julieta (sul de Moçambique), Luisa (etnia xingondo), Saly (etnia maconde) e Mauá (etnia macua). Elas formam junto com Tony (etnia machangana) "um hexágono amoroso" (CHIZIANE, 2004, p.58).

A tradição oral africana permeia a narrativa. Uma representante dessa cultura é, especificamente, a lenda da princesa Vuyazi, a princesa insubmissa estampada na lua:

"Era uma vez uma princesa. Nasceu da nobreza mas tinha o coração de pobreza. Às mulheres sempre se impôs a obrigação de obedecer aos homens. É a natureza. Esta princesa desobedecia ao pai e ao marido e só fazia o que queria. Quando o marido repreendia ela respondia. Quando lhe espancava, retribuía. Quando cozinhava galinha, comia moelas e comia coxas, servia ao marido o que lhe apetecia. Quando a primeira filha fez um ano, o marido disse: vamos desmamar a menina e fazer outro filho. Ela disse que não. Queria que a filha mamasse dois anos como os rapazes, para crescer forte como ela. Recusava-se a servi-lo de joelhos e apararlhe os pentelhos. O marido, cansado da insubmissão, apelou à justiça do rei, pai dela. $\mathrm{O}$ rei, magoado, ordenou ao dragão para lhe dar um castigo. Num dia de trovão, o dragão levou-a para o céu e a estampou na lua, para dar um exemplo de castigo ao mundo inteiro. Quando a lua cresce e incha, há uma mulher que se vê no meio da lua, de trouxa à cabeça e bebé nas costas. É Vuyazi, a princesa insubmissa estampada na lua. É a Vuyazi, estátua de sal, petrificada no alto dos céus, num inferno de gelo. É por isso que as mulheres do mundo inteiro, uma vez por mês, apodrecem o corpo em chagas e ficam impuras, choram lágrimas de sangue, castigadas pela insubmissão de Vuyazi” (CHIZIANE, 2004, p.157). 
O excerto acima emprega a fórmula clássica para iniciar uma narrativa ficcional: "Era uma vez uma princesa". A lenda é transcrita em frases curtas, com rimas: nobreza/pobreza/natureza. O tempo verbal utilizado no pretérito imperfeito dá ritmo à narrativa: desobedecia/queria/repreendia/respondia/retribuía. Verificam-se também, por entre as linhas dessa narrativa, os modos de funcionamento do sistema patriarcal: a obediência aos homens - pai e marido, os comportamentos diferenciados relacionados à educação do homem e da mulher, o castigo para a desobediência às tradições, entre outros. Rami, a protagonista, ao longo do romance, irá retomá-los em vários momentos.

Interessante observar que o termo macua "niketche", o ritual iniciático e a lenda da princesa Vuyazi podem representar a dicotomia cultural pertinente ao norte e ao sul de Moçambique. A dança representa o sul com um posicionamento mais liberal e a lenda representa o norte do país, que segue um modelo paradigmático judaico-cristão, fortemente influenciado pelo patriarcalismo colonial europeu. Essa dicotomia entre Norte-Sul é bem representada nestes trechos:

\footnotetext{
- Mulheres bonitas só no norte, seus machanganas ${ }^{3}$ ! As nortenhas são leves e livres. As nortenhas são belas. As vossas mulheres são pesadas, são grossas, têm o rabo grande de comer tanto amendoim!

A poligamia é um sistema com regras próprias, e, nessa matéria, o sul é diferente do norte [...] Vocês do norte, são escravos delas. Trabalham a vida inteira só para elas. Até os filhos têm apelido da mãe. Que tipo de homens vocês são?

- E vocês do sul são brutos, tratam as mulheres como bichos. Alguém, neste mundo, sabe que é o verdadeiro pai dos filhos da mulher? O senhor que tanto nos insulta, tem a certeza de que os filhos que diz serem seus o são, de certeza? Na nossa terra os filhos têm o apelido da mãe, sim. Pai é dúvida, mãe é certeza. Um galo não choca ovos, nunca. É bom dar a César o que é de César. (CHIZIANE, 2004, p.207).

Nortenhos ou sulistas, cada um quer ser mais alto e chegar primeiro ao umbigo do céu. Cada um quer ser garça, falcão, albatroz, para alcançar mais depressa o alto do monte onde ainda pende um cacho de banana e uma galinha assada no braseiro do mundo. (CHIZIANE, 2004, p.210)
}

Assim como as lendas e os rituais de iniciação que compõem a tradição oral, formalmente, os provérbios marcam essa presença na linguagem do texto.

\section{Provérbio - o poder da palavra}

O provérbio, muito embora seja conhecido por muitos em nossa sociedade, enfrenta uma dificuldade imensa quanto à sua definição. Todavia, é feito um pequeno esclarecimento de alguns dos conceitos vigentes para uma maior compreensão a seu respeito nesse contexto. Conforme Luiz Costa Lima (1974, p.14) destaca-se esta afirmação:

\footnotetext{
${ }^{3}$ Machanganas: uma das etnias tsonga.
} 
A armadura simples do provérbio permite, por conseguinte, que ele seja manejado com facilidade pelo falante; sua formação poética promove a sua retenção; a sabedoria que contém, sua aplicação a um número indefinido de situações. Pelo provérbio, com efeito, é todo um saber comunal que, elipticamente, se precisa e condensa.

Muitas definições possuem traços em comum. Tal como consta no Dicionário Houaiss de Língua Portuguesa (2001, p.2321), o provérbio é uma "frase curta, de origem popular, com ritmo e rima, rica em imagens, que sintetiza um conceito a respeito da realidade ou uma regra social ou moral. Provérbio, adágio, dito, ditado, rifão, máxima.”

Também Helena Duarte (2006, p.32), após muitas pesquisas, define assim o provérbio: "um enunciado cristalizado, pertencente ao patrimônio linguístico, mas de autoria anônima, transmitido oralmente, ao qual subjaz uma verdade de caráter geral e cuja autonomia sintática permite a sua conexão com as múltiplas situações em que se aplica.”

Logo, sabemos que o provérbio é considerado um texto tradicional como os mitos e os símbolos. Possui inúmeros traços que o definem: origem remota e anônima, conteúdo metafórico, caráter diacrônico, valor semântico de verdade universal. Seu caráter rítmico e sua formulação facilitam a memorização, como elucida Ong (1998, p.45-46) nessa passagem:

As fórmulas ajudam a implementar o discurso rítmico, assim como funcionam, por si só, como
apoios mnemônicos, como expressões fixas que circulam pelas bocas e pelos ouvidos de todos
$[\ldots]$ "Dividir para conquistar." "Errar é humano, perdoar é divino". [...] Fixas, muitas vezes
ritmicamente equilibradas, expressões desse e de outros tipos podem ser ocasionalmente
encontradas impressas; na realidade, podem ser "procuradas" em livros de adágios, mas nas
culturas orais não são eventuais, são constantes. Elas formam a substância do próprio
pensamento. Sem elas, este é impossível em qualquer forma extensa, pois é nelas que consiste.
Nessas culturas orais, a própria lei está encerrada em adágios formulares, provérbios, que não
constituem meros adornos jurídicos, mas são, em si mesmos, a lei.

Dominique Maingueneau, por intermédio de sua perspectiva linguística, assevera-nos que o indivíduo, ao utilizar o provérbio, "toma sua asserção como o eco, a retomada de um número ilimitado de enunciações, anterior do mesmo provérbio", como vemos:

O provérbio representa um enunciado limite: o "locutor" autorizado que o valida, em lugar de ser reconhecido apenas por uma determinada coletividade, tende a coincidir com o conjunto de falantes da língua, estando aí incluído o indivíduo que o profere. Este último toma sua asserção como o eco, a retomada de um número ilimitado de enunciações, anteriores do mesmo provérbio. (MAINGUENEAU: 1989, p.101)

Esse eco possui, portanto, o saber da tradição oral. Reativá-lo na escrita significa reativar no texto esse conhecimento, que modela, (re)cria ou, simplesmente, usa o provérbio para complementar uma afirmação. 


\section{A voz na letra}

Olho para todas elas. Mulheres cansadas, usadas. Mulheres belas, mulheres feias. Mulheres novas, mulheres velhas. Mulheres vencidas na batalha do amor. Vivas por fora e mortas por dentro, eternas habitantes das trevas. Mas por que se foram embora os nossos maridos, por que nos abandonam depois de muitos anos de convivência? Por que nos largam como trouxas, como fardos, para perseguir novas primaveras e novas paixões? Por que é que, já na velhice, criam novos apetites? Quem disse aos homens velhos que as mulheres maduras não precisam de carinho? (CHIZIANE, 2004, p.12)

Muito embora o viés elaborado aqui seja pela perspectiva da oralidade, não se consegue fugir da temática feminina, uma vez que a narrativa de Chiziane está impregnada dessas vozes, a mulher é o mote central do romance. Desse modo, os comentários sobre o universo feminino são inevitáveis. A maestria e a simplicidade que a autora possui, como contadora de histórias, tece de forma arrebatadora todo o tecido narrativo, envolvendo-nos. Tal envolvimento torna a leitura do romance prazerosa, no sentido barthesiano da sensibilidade textual: "O texto que o senhor escreve tem de me dar prova de que ele me deseja. Essa prova existe: é a escritura. A escritura é isto: a ciência das fruições da linguagem, seu kama-sutra (...).” (BARTHES, 1996, p.11).

O ditado por ser uma "construção metafórica ou conotativa, diz respeito a verdades gerais e faz um julgamento de valor", carrega consigo uma bagagem mnemônica muito intensa, como a narradora Rami cita: "Esta imagem é minha certeza, o meu subconsciente, resgatando ditados e saberes mais escondidos na memória” (CHIZIANE, 2004, p.172). Nessa perspectiva, enfatiza Amadeu Amaral:

\footnotetext{
Uma das formas de conhecimento da história do pensamento social no correr dos séculos está presente em um vasto número de expressões, muitas vezes caracterizadas como populares, as quais seriam portadoras das vivências de uma ou mais gerações e que funcionariam como instrumentos de conduta aptos para serem aplicados no cotidiano. (AMARAL, 1948, p.242).
}

Paulina Chiziane, em Niketche, vale-se da fala e não omite a fonte: "A voz popular diz que a mulher do vizinho é sempre melhor que a minha." (CHIZIANE, 2004, p.37). E também, "Vidro quebrado é mau "agoiro" 4 , confirma-se a sabedoria popular." (CHIZIANE, 2004, p.27). Nesses trechos, o artifício elaborado pela autora para trazer essa voz popular é citar a fonte e, na sucessão linear da sintaxe, inserir o provérbio, como é percebido nos exemplos demonstrados. Além disso, outras maneiras para utilização dos provérbios é empregada, como veremos ao longo desse trabalho.

Terezinha Taborda Moreira, em $O$ vão da voz: a metamorfose do narrador na ficção moçambicana, examina o provérbio nesta perspectiva:

\footnotetext{
${ }^{4}$ Ortografia moçambicana.
} 
Ora a inserção do provérbio no enunciado confirma o sentido do texto, realizando uma espécie de registro da uma "fala comum" que é reativada no texto para confirmar a própria fala do narrador: ora a sua citação exerce uma função desconstrutiva e irônica do conteúdo posto. No caso da confirmação, o provérbio poderia aturar como elemento de ligação entre o texto e o extratexto. Como tal, o provérbio implicaria uma instituição social, a qual, por sua vez, implica uma situação de enunciação convencionalmente definida: a função pragmática do provérbio. Funcionaria como conector, referindo-se expressamente ao texto e ao intertexto, integrando de modo manifesto um e outro. (MOREIRA, 2005, p. 114-115)

Seguindo essa linha, no referido romance de Paulina Chiziane apresenta-se o emprego de provérbios sob forma cristalizada, que é também criada, recriada, invertida ou acrescida a partir da estrutura proverbial original.

\section{Provérbio cristalizado para falar do universo feminino}

A epígrafe traz o provérbio zambeziano: "Mulher é terra. Sem semear, sem regar, nada produz" (CHIZIANE, 2004, p.07). Esse provérbio reflete uma dicotomia: por um lado, o peso da tradição, a mulher como serventia apenas para a procriação; por outro lado, podemos analisar por este viés: a mulher como fonte produtora e reprodutora dos filhos e também da tradição. No decorrer da narrativa, ocorre um contraponto a essa idéia de mulher simplesmente reprodutora por intermédio da fala da personagem-narradora: "De repente lembro-me de uma frase famosa - ninguém nasce mulher, torna-se mulher. ${ }^{5}$ Onde terei eu ouvido esta frase?” (CHIZIANE, 2004, p.35). Rami, na continuação da narrativa, descreve todos os ritos do pelos quais passou até "tornar-se mulher". Entretanto, com a descoberta da poligamia, o aprendizado ainda não havia terminado.

Nota-se que após a famosa frase de Simone de Beauvoir, filósofa e escritora francesa feminista, Paulina Chiziane insere na fala da personagem uma observação - Onde terei eu ouvido essa frase -, visto que Rami não poderia ter lido um livro feminista. Assim, ao empregar esse recurso a escritora acrescenta veracidade à fala da protagonista.

Fiquei a saber como no amor os olhos se expressam. Olhos de gata. Olhos de serpente. Olhos magnéticos. Olhos sensuais. Não há mulheres feias no mundo, disse a conselheira - 0 amor é cego. Existem, sim, mulheres diferentes. (CHIZIANE, 2004, p.43)

Neste contexto, o provérbio "O amor é cego" é empregado em sua forma cristalizada, na argumentação da conselheira amorosa: "Não há mulheres feias no mundo, disse a conselheira - o amor é cego. Existem, sim mulheres diferentes" (CHIZIANE, 2004, p.43). Rami traz à tona um número significativo de mulheres diferentes: suas rivais, sua mãe, sua tia e tantas outras mulheres com as quais dialoga. Além disso, a narradora-protagonista

\footnotetext{
${ }^{5}$ BEAUVOIR, Simone de. O Segundo Sexo. Volume 2 A Experiência Vivida. . Tradução de Sérgio Milliet. Rio de Janeiro: Nova Fronteira, 1980.
} 
estabelece interlocuções consigo mesma através do seu espelho. Ela mergulha nesse universo feminino, modificando sua visão sobre a condição feminina em seu país. Em sua escrita, evidencia-se o diálogo polifônico como nos conceitua o teórico russo Mikhail Bakthin:

(...) A essência da polifonia consiste justamente no fato de que as vozes, aqui, permanecem independentes e, como tais, combinam-se numa unidade de ordem superior à da homofonia. $\mathrm{E}$ se falarmos de vontade individual, então é precisamente na polifonia que ocorre a combinação de várias vontades individuais, realiza-se a saída de princípio para além dos limites de uma vontade. Poder-se-ia dizer assim: a vontade artística da polifonia é a vontade de combinação de muitas vontades, a vontade do acontecimento. (BAKHTIN, 2005, p.21)

\section{Provérbio com acréscimo, entretanto com sentido preservado}

Rami, diante de uma das amantes de seu marido Tony, pensa: "Vou fazer a prova dos nove e saldar esta conta, olho por olho, dente por dente" (CHIZIANE, 2004, p.21). "Fazer a prova dos nove" é um conhecimento oriundo da matemática, é a maneira de testar se os cálculos com números inteiros estão corretos. Eis, então, a referida citação:

Ela fala-e do alto da catedral por ser mais amada do que eu. Eu sofro, quase que morro, como se ela estivesse a meter-me uma tesoura de aço na raiz do meu coração. Vocês sabem o que dói ser tratada com altivez por quem vos rouba o marido? Eu não vou deixar-me rastejar diante de uma ladra sentimental, não posso. Ela é uma mulher, eu também sou. Tenho fogo no corpo, vou libertá-lo, tenha a santa paciência. Vou fazer a prova dos nove e saldar esta conta, olho por olho, dente por dente. (CHIZIANE, 2004, p. 21)

A expressão "fazer a prova dos nove" tornou-se popular, sendo muito usada na vida cotidiana, quando se quer ter a certeza do fato ou do que está se falando. Por conseguinte a autora, ao trazer da oralidade um termo para o texto, a voz para a letra, aciona na memória do leitor todo esse conhecimento sintetizado:

Deste modo, os provérbios não são obras secundárias e, além disso, revelam-se como sendo belos "resumos" de longas e amadurecidas reflexões, resultado de experiências mil vezes confirmadas. O caráter anônimo dos provérbios traduz a sua profunda inserção no âmago da experiência e da vida coletiva, depois de longas rodagens e experiências. (AGUESSY, 1977, p.118.)

Já “olho por olho, dente por dente" (CHIZIANE, 2004, p.21), originou-se do Código de Hamurábi (1780 a.C.), no qual a escala das penas é descrita segundo os delitos e crimes cometidos. Na narrativa de Paulina Chiziane é utilizada a lei do código mais de uma vez.

Ele barra-me a passagem para que eu não saia. Empurro-o. Se não fosse o cansaço e a minha fraqueza, dava-lhe uma valente tareia, e fazia-lhe pagar tudo, dente por dente, braço por braço. Mesmo assim, consigo dar-lhe uma violenta chapada. Ele não reage. Pego nas malas disposta a sair. Ele agarra as malas disposto a arrancá-las das minhas mãos. Disputamo-las. (CHIZIANE, 2004, p.234)

Em uma discussão com Tony, a narradora diz: "Se não fosse o meu cansaço e a minha fraqueza, dava-lhe uma valente tareia, e fazia-lhe pagar tudo, dente por dente, braço por 
braço" (CHIZIANE, 2004, p.234). Nesse contexto, ocorre um acréscimo lexical ao já conhecido "dente por dente", sendo que a briga era tão violenta que seria "braço por braço".

Sobressai-se, no contexto desse romance, a luta da mulher, representada pela narradora-protagonista, Rami. Nessa luta, para afirmar-se como uma mulher dona da palavra e de suas ações, Rami, após consultar a conselheira e participar de quinze aulas, ressalta: "Estas aulas são os meus ritos de iniciação" (CHIZIANE, 2004, p.44). Ao longo do corpo narrativo, ela declara que a sua educação foi desenvolvida aos moldes dos costumes europeus: "Aprendi todas aquelas coisas das damas européias, como cozinhar bolinhos de anjos, bordar, boas maneiras, tudo coisas da sala. Do quarto nada!” (CHIZIANE, 2004, p.45). Sendo assim, todo esse aprendizado não tinha serventia para (re)conquistar o seu marido e ainda argumenta: "Os livros escritos por padres invocavam Deus em todas as posições. Sobre a posição a dois nada, nada!" (CHIZIANE, 2004, p.44-45). Nesses excertos, destaca-se a duplicidade educacional das tradições do Norte e do Sul moçambicano. Vê-se no recorte abaixo quando Rami explicita sobre a poligamia, as influências islâmicas e cristãs sendo evidenciadas e o influxo também se reflete no regime político-cultural:

Poligamia é o destino de tantas mulheres neste mundo desde os tempos sem memória. Conheço um povo sem poligamia: o povo macua. Este povo deixou as suas raízes e apoligamou-se por influência da religião. Islamizou-se. Os homens deste povo aproveitaram a ocasião e converteram-se de imediato. Porque poligamia é poder. Porque é bom ser patriarca e dominar. Conheço um povo com tradição poligâmica: o meu, do sul do meu país. Inspirado no papa, nos padres e nos santos, disse não à poligamia. /Cristianizou-se. (...) Os homens é que defendem a terra e a cultura. As mulheres apenas preservam. No passado os homens deixaram-se vencer pelos invasores que impuseram culturas, religiões e sistemas a seu bel-prazer. Agora querem obrigar as mulheres a rectificar a fraqueza dos homens. (CHIZIANE, 2004, p.92)

Rami, mulher que vive o conflito entre tradição e modernidade, entre rituais iniciáticos e a educação judaico-cristã, cheia de pecados e de culpa. É uma mulher forte e essa força é evidenciada na tessitura narrativa, no seu discurso. Seja através do uso dos provérbios, seja por intermédio da escolha do léxico.

Corro para o meu espelho e desabafo.

- Sonhei tanto com este momento, tudo se desmoronou, que faço agora, espelho meu?

- Onde está o espírito de luta, amiga minha? Se falhou hoje, podes tentar outra vez!

Obrigada, espelho meu. Perder a batalha não é perder a guerra. Amanhã será outro dia.(CHIZIANE, 2004, p.48)

No trecho acima evidenciado, o provérbio "Perder a batalha não é perder a guerra" (CHIZIANE, 2004, p.48) é empregado no momento em que Rami, após ter assistido as aulas da conselheira amorosa, tenta colocar em prática o seu aprendizado, modificando seu modo de vestir, cuidados com a pele, perfume, tudo para reconquistar seu marido. Entretanto Tony a surpreende: "pareces uma borboleta. Parece açafrão. Piripiri maduro. O que te inspira a esses 
gostos tão espampanantes?" (CHIZIANE, 2004, p.48). Os planos dela não atingiram o objetivo proposto: “a conquista”. Todavia essa questão não iria desanimá-la: “Amanhã será outro dia."

Sei o que ele sofre, conheço o pensamento dos homens. Não suportam a idéia de serem abandonados. Conheço alguns que ficaram impotentes, que enlouqueceram ou ficaram alcoólicos, só por terem levado um par de chifres que nem valeu nada. As mulheres são mais fortes, superam o abandono com mais valentia. São trocadas em cada dia. Traídas. Seduzidas. Abandonadas com filhos nos braços. Compradas. Espancadas em cada dia, mas elas resistem. Suportam o licahoe e os cintos de castidade quando o homem vai para a guerra, ou para qualquer aventura. Na velhice, elas são acoitadas pelos próprios filhos, acusadas de feitiçaria. E elas rezam e agradecem a Deus por cada tormento. É por isso que elas cantam, e dançam por tudo e por nada. Quem canta, seu mal espanta. (CHIZIANE, 2004, p.278)

Essa força que suporta a dor, como se denota na apresentação sequencial de verbos no particípio: trocadas, traídas, seduzidas, abandonadas, compradas, espancadas, acoitadas, acusadas. É o impacto da palavra que deflagra a violência corporal e moral imposta às mulheres. A potencialidade também se demonstra com os verbos no presente do modo indicativo que servem como antíteses dos anteriores: agradecem, rezam, cantam e dançam. Tais termos dão à narradora ânimo para enfrentar situações adversas que não são deduzidas do semanticismo verbal, mas da ação positiva que deles emana. E, a autora finaliza com o provérbio: "Quem canta, seu mal espanta." (CHIZIANE, 2004, p.278).

No ocidente, a música e a dança estão mais associadas ao culto da alegria e da carnavalização, no entanto, na tradição moçambicana, o significado carrega uma duplicidade dicotômica, pois celebra tanto o amor como a dor. Niketche, a dança do amor, é a dança das culturas, a dança das mulheres, na fluidez do tecido narrativo desse romance. O canto e a dança, princípios de rituais autóctones, são preservados até hoje. Para tanto, exemplifiquemos:

Titubeio uma canção antiga daquelas que arrastam as lágrimas à superfície. Nessa coisa de cantar, tenho as minhas raízes. Sou de um povo cantador. Nesta terra canta-se na alegria e na dor. A vida é um grande canto. (CHIZIANE, 2004, p.15)

No trecho a seguir, também é evidente este aspecto:

- Celebro o amor e a vida. Danço sobre a vida e a morte. Danço sobre a tristeza e a solidão. Piso para o fundo da terra todos os males que me torturaram. A dança liberta a mente das preocupações do momento. A dança é uma prece. Na dança celebro a vida enquanto aguardo a morte. Dançar. Dançar a derrota do meu adversário. Dançar na festa do meu aniversário. Dançar sobre a coragem do inimigo. Dançar no funeral do ente querido. Dançar à volta da fogueira na véspera do grande combate. Dançar é orar. Eu também quero dançar. A vida é uma grande dança. (CHIZIANE, 2004, p.16)

Na passagem logo abaixo, ainda se pode observar a representação da dança: 
- Ao som das palmas e das cantigas, giro para cá, para lá, para cima, para baixo, para a esquerda, para a direita, na dança desafogo, dança oração, dança liberdade. (CHIZIANE, 2004, p.292)

Podemos perceber também nessas citações características da oralidade que se evidenciam no texto, como as figuras de linguagem: o assíndeto "Dançar", as antíteses "vida/morte", as repetições “dança desafogo, dança oração e dança liberdade". Essas características perpassam o romance. Mais adiante, nota-se outras expressões proverbiais:

Mulher é o eterno problema e não há como solucioná-lo. Ela é um projeto imperfeito. Toda ela é feita de curvas. Não tem sequer uma linha recta, não se endireita. É surrealista? Não. É abstracta? Também não. É gótica, isso sim. Tem arcos, abóbadas, ogivas. Ela é mole, ela é fraca, ela é teimosa como a gota de água que tanto bate até que fura. Mulher fala muito e fala de mais. Por isso ela é silêncio, é sepultura, vivendo no poço fundo, no abismo sem fim. (CHIZIANE, 2004, p.208)

O provérbio original "água mole em pedra dura tanto bate até que fura" denota persistência, a exemplo da água (elemento líquido) que no movimento contínuo consegue perfurar uma pedra (elemento sólido). Do mesmo modo, o sujeito, persistindo em suas ações, atingirá os objetivos propostos. A autora de Niketche emprega esta asserção: "ela é teimosa como a gota de água que tanto bate até que fura" (CHIZIANE, 2004, p.208). Assim, é feita analogia entre a ideia do provérbio e o significado reelaborado que se dá a partir dele na prosa de Chiziane. O termo "teimosa" expressa um aspecto negativo e contraditório em relação ao sentido original proverbial porque, no contexto, vale-se a autora de todas as qualificações femininas, de forma depreciativa. Para indagar à Deus, ela diz: "por que me fizeste mulher?". Desse modo, Chiziane traça um contraponto com o sujeito masculino: "O homem é aquele por quem todos os sinos dobram". 6

\section{Provérbio original cristalizado relativo à religião cristã}

O provérbio "a César o que é de César" (CHIZIANE, 2004, p.207), oriundo da Bíblia, é uma lição de justiça, dar a cada um o que lhe é devido, como vemos neste excerto:

Então, retirando-se os fariseus, projetaram entre si comprometê-lo no que falasse. E enviaramlhe seus discípulos, juntamente com os herodianos, que lhe disseram: Mestre, sabemos que és verdadeiro, e não se te dá de ninguém, porque não levas em conta a pessoa dos homens; dizenos, pois, qual é o teu parecer: é lícito dar tributo a César ou não? Porém Jesus, conhecendo a sua malícia, disse-lhes: Por que me tentais, hipócritas? Mostrai-me cá a moeda do censo. E eles lhes apresentaram um dinheiro. E Jesus lhes disse: De quem é esta imagem e inscrição? Responderam-lhe eles: De César. Então lhes disse Jesus: Pois daí a César o que é de César, e a Deus o que é de Deus. E quando ouviram isto, admiraram-se, e deixando-o se retiraram. (Bíblia Sagrada - Mateus, XXII: 15-22; Marcos, XII: 13-17).

\footnotetext{
${ }^{6}$ Intertextualidade com o romance do escritor americano Ernest Hemingway Por Quem os Sinos Dobram, escrito em 1940.
} 
Na obra Niketche, como vemos abaixo, a autora utiliza a mesma forma proverbial:

- E vocês do sul são brutos, tratam as mulheres como bichos. Alguém, neste mundo, sabe quem
é o verdadeiro pai dos filhos da mulher? O senhor, que tanto nos insulta, tem a certeza de que
os filhos que diz serem seus o são, de certeza? Na nossa terra os filhos têm o apelido da mãe,
sem. Pai é dúvida, mãe é certeza. Um galo não choca ovos, nunca. É bom dar a César o que é
de César. (CHIZIANE, 2004, p.207)

Denotam-se com a utilização do provérbio as influências na tradição moçambicana de ordem da cultura judaico-cristã. Moçambique é um lugar de cruzamento de diferentes povos, um mosaico cultural. Em O conto Moçambicano Escritas pós-coloniais, Maria Fernanda Afonso afirma que a situação geográfica de Moçambique permitiu-lhe muito cedo a entrar em contato com diferentes povos, comerciantes chineses e, principalmente, árabes. Na realidade, até a chegada dos portugueses, a costa oriental africana á arabizada e islamizada (AFONSO, 2004, p.13-14). A partir de 1498 com a chegada de Vasco da Gama à Ilha de Moçambique, os portugueses estabeleceram-se na região, influenciando a cultura local.

Vou ao quarto e dialogo com o meu espelho.

- Espelho meu, o que será de mim?

O espelho dá-me uma imagem de ternura e responde-me com a maior lucidez de sempre.

- Não serás a primeira a divorciar, nem a última. Os divórcios acontecem todos os dias, como os nascimentos e as mortes, mas tranqüiliza-te. Há uma grande diferença entre a vontade do homem e a vontade de Deus. O que Deus põe, o homem não dispõe. (CHIZIANE,2004, p.171)

No provérbio "O que Deus põe, o homem não dispõe" a autora inverte o conhecido "O homem propõe e Deus dispõe" (Homo proponit, sed Deus disponit), oriundo de Tomás de Kempis $^{7}$. A narradora-protagonista relativiza sua união com Tony, um casamento cristão perante a lei de Deus, indissolúvel, e depara-se com o pedido de divórcio de seu marido. Mesmo que o casamento seja protegido por leis divinas, o homem (nesse caso, Tony) confronta-se com Deus, desejando quebrar o pacto matrimonial.

\section{Provérbio cristalizado para indicar o status quo do homem}

"Beira" era o nome dado ao que, na atualidade, chamamos de aba ou beiral do telhado, um pequeno prolongamento do telhado da casa, que nos tempos coloniais, caracterizava as casas portuguesas elitizadas, para enfeitá-las e protegê-las da chuva. No Brasil, ainda pode ser vista essa arte arquitetônica colonial nas residências em cidades tais como Ouro Preto,

\footnotetext{
${ }^{7}$ Tomás de Kempis (Kempen, Renânia, 1379 ou 1380 - 25 de julho de 1471, mosteiro de Saint Agnetenberg, Zwolle), foi um monge e escritor místico alemão. São-lhe atribuidas cerca de 40 obras, o que o torna o maior representante da literatura devocional moderna. Um dos textos que lhe são atribuídos é o Imitação de Cristo, obra de inegável influência no cristianismo. Thomas Haemerken ou Tomás de Kempis.

Disponível em: http://pt.wikipedia.org/wiki/Tom\%C3\%A1s_de_Kempis. Acesso em 10/05/2010.
} 
Mariana, Tiradentes (Minas Gerais), e Parati (Rio de Janeiro). Em outros estados também é visível esse estilo por onde passaram as abastadas famílias portuguesas. Dessa maneira, a beira ficou conhecida como sinônimo de boa fortuna. Para quem não a possuísse, então, surgiu a expressão "sem eira, nem beira", qualificando aquele sujeito que não possui bens, que vive sem recursos, na miséria. Como percebemos, tal termo é de origem portuguesa, sendo que Brasil e África, aqui representada por Moçambique, foram colônias de Portugal e deixaram-nos também como herança o provérbio citado. Por conseguinte, o mesmo é empregado em sua forma cristalizada, complementando o texto. Face a essas observações, cita-se o excerto abaixo:

Lá no norte, o rio Zambeze derramou as suas ondas que mataram lagartos, capim, formigas, pessoas. Arrastou crocodilos do seu leito para as aldeias, que se escondem na pestilência dos lodos e comem crianças. Cá no sul, os jovens consomem droga, não vão à escola, violam mulheres e roubam carros. Alguns dos homens furiosos nesta sala foram guerreiros e libertaram o país inteiro, mas não têm eira nem beira, muito menos um pedaço de terra para construir sua morada,vivem debaixo de uma árvore onde destilam aguardente que bebem para esquecer, traficam o sexo das filhas e vendem soruma. (CHIZIANE, 2004, p.209-210)

Levando em conta os aspectos analisados neste trabalho, podemos citar a socióloga Ruth Finnegan, em Oral Literature in África (1970, p.393), obra em que a estudiosa afirma que os provérbios podem começar uma história, sublinhá-la, terminá-la, talvez mais do que qualquer outra forma, condensam a memória da oralidade e da tradição.

Nas palavras de Moreira, em $O$ vão da voz: a metamorfose do narrador na ficção moçambicana (2005, p.120), a autora assevera nos seguintes termos:

\begin{abstract}
Nos textos os provérbios se constituem como elementos determinantes da enunciação narrativa, manifestando-se como uma forma, uma palavra, um sentido que se coloca em um tempo e um contexto específico. Eles se ligam, portanto, ao acontecimento da experiência enunciada. (...) Ao entrar no texto, o provérbio se anuncia como fragmento de um mosaico. Num mosaico os elementos não são distintos, mas semelhantes.
\end{abstract}

\title{
9 Conclusão
}

Ocorre ao longo do livro uma metamorfose, o trajeto percorrido pela narradorapersonagem não só modifica a sua vida, como ainda a vida das outras mulheres (Julieta, Luisa, Saly e Mauá). Paulina Chiziane, nesse romance, esboça com palavras o retrato da mulher na cultura africana, num desenho realista e poético. A autora revela através das letras, o corpo velado sob as cores fortes da África por intermédio dos vestidos coloridos, que cobrem o corpo, cores fortes tais quais as impressas nas telas do pintor moçambicano Roberto Chichorro $^{8}$. Ao mesmo tempo, desvela o corpo e a alma feminina, mostrando as cicatrizes tatuadas pelas guerras, pelos filhos fecundados sem consentimento, pelos problemas de

\footnotetext{
${ }^{8}$ Disponível em: http://www.chichorro.com/obra.html .Acesso em 12 maio 2010.
} 
aculturação gerados pela colonização. A romancista denuncia, inclusive, todas as adversidades oriundas de uma sociedade poligâmica e paternalista. Desse modo, o ignóbil poder econômico-político-social submete desumanamente a condição humana. A autora transcende territórios, respeitando as devidas culturas.

“O homem sábio é o que conhece a palavra e que é capaz de a transmitir como conhecimento e qualidade do verbo, passando desta maneira ao longo da cadeia de gerações o fio ininterrupto do saber" (AFONSO, 2004, p.206). Em Niketche: uma história de poligamia, Paulina Chiziane tece a narrativa com o fio do saber, traz a voz, as histórias e a cultura da mulher africana, seja do norte ou seja do sul, mulher cindida entre a tradição e a modernidade. Ela provoca um diálogo reflexivo sobre a cultura herdada: Niketche (ritual de iniciação), lobolo (dote), Tchinga (prática do levirato), xitique (sistema tradicional de poupança), poligamia e outros elementos da tradição. Todavia a autora não propõe rompimentos, propõe diálogo, usando a personagem como uma porta-voz das mulheres africanas, apesar de apresentar um mosaico de diferenças. As mulheres aprendem entre si, ocorre uma união das mulheres para a melhoria de suas vidas. Eis que o fio da vida e da tradição se entrelaçam.

\section{Referências}

AFONSO, Maria Fernanda. O conto moçambicano: Escritas pós-coloniais. Lisboa: Editora Caminho S. A., 2004.

AGUESSY, Honorat. "Visões e percepções tradicionais". In: Lisboa: Edições 70, 1977. . Introdução à cultura africana.

AMARAL, Amadeu. Tradições populares. São Paulo: Instituto Progresso Editorial, 1948.

BAKHTIN, Mikhail. Problemas da poética de Dostoiévski. Trad. Paulo Bezerra. 3. ed. Rio de Janeiro: Forense Universitária, 2005.

BARTHES, Roland. O prazer do texto. Trad. J. Guinsburg. 4. ed. São Paulo: Perspectiva, 1996.

BEAUVOIR, Simone de. O Segundo Sexo. Volume 2 A Experiência Vivida. . Tradução de Sérgio Milliet. Rio de Janeiro: Nova Fronteira, 1980.

BUSARELLO, Raulino. Dicionário Básico latino-português. Florianópolis: Editora da UFSC, 2004.

CHIZIANE, Paulina. Niketche: uma história de poligamia. São Paulo: Companhia das Letras, 2004. Publicado em 2002. . Niketche: uma história de poligamia. Lisboa: Editora Caminho, 2002. Contracapa.

COUTO, Mia. O fio das missangas: contos. São Paulo: Companhia das Letras, 2009. 
HAMPATÉ BÂ, Amadou. História Geral da África: Metodologia e pré-história da África. São Paulo: UNESCO, 1980.

HAVELOCK, Eric. “A equação oralidade - cultura escrita: uma formula para a mente moderna".In: OLSON, David R. \& TORRANCE, Nancy. (orgs.) Cultura escrita e oralidade. São Paulo: Ática, 1995.

HOUAISS, Antônio e Villar, Mauro de Salles. Dicionário Houaiss da Língua Portuguesa. Rio de Janeiro: Objetiva, 2001.

Larousse cultural - Dicionário da Língua Portuguesa. São Paulo: Editora Nova Cultural Ltda., 1992.

LIMA, Luiz Costa. Mito e provérbio em Guimarães Rosa. Colóquio de Letras, número 17, 1974.

MOREIRA, Terezinha Taborda. $O$ vão da voz: a metamorfose do narrador na ficção moçambicana. Belo Horizonte: Edições Horta Grande Ltda., 2005.

MAINGUENEAU, Dominique. Novas tendências em análise do discurso. Campinas: Pontes, 1989.

ONG, Walter. Oralidade e cultura escrita. Campinas: Papirus, 1998. 